\title{
Habitat heterogeneity influences cold-seep macrofaunal communities within and among seeps along the Norwegian margin. Part 2 : contribution of chemosynthesis and nutritional patterns
}

\author{
Carole Decker ${ }^{*}$, Karine Olu \\ ${ }^{1}$ IFREMER Département Etude des Ecosystèmes Profonds, Plouzané, France \\ *: Corresponding author : Carole Decker, email address : carole.decker@ifremer.fr
}

\begin{abstract}
:
The relative contribution of chemosynthesis in heterotrophic fauna at seeps is known to be influenced by depth and by habitat. Using stable isotopes of carbon and nitrogen, we investigated macro- and megafaunal nutritional patterns in Norwegian margin cold seeps by comparing food webs both among habitats within a seep site and between different sites. The very active Håkon Mosby mud volcano (HMMV) is characterized by geochemical gradients, microbial activity and faunal zonation from the centre to the periphery. The Storegga Slide (600-900 m depth) has pockmarks with patchy less active seeps, and also shows concentric zonation of habitats but at much smaller spatial scale. The dominant carbon source for macrofaunal nutrition in both areas was chemosynthetically fixed and the bulk of organic carbon was derived from sulphur-oxidizing bacteria. In HMMV, food chains were clearly separated according to habitats, with significantly lighter $\delta^{13} \mathrm{C}$ signatures on microbial mats and adjacent sediment $(-33.06$ to $-50.62 \%)$ than in siboglinid fields $(-19.83$ to $-35.03 \%)$. Mixing model outputs revealed that the contribution of methane-derived carbon was small in siboglinid fields $(0-$ $17 \%)$ but significant (39-61\%) in the microbial mats. Moreover, the variability of macrofauna signatures within this later habitat suggests the co-occurrence of two food chains, one based on primary production via methanotrophy and the other via sulphide oxidation. The length of the food chains also varied among habitats, with at least one more trophic level in the siboglinid fields located at the periphery of the volcano. Conversely, in Storrega pockmarks, faunal $\delta^{13} \mathrm{C}$ signatures did not vary among habitats but among species, although separate food chains seem to co-occur. The small size of the seepage areas and their lower fluxes compared to HMMV allow more background species to penetrate the seep area, increasing the range of $\delta^{15} \mathrm{~N}$ and the trophic level number. Probably due to the higher flux of photosynthetic particulate organic carbon, the overall chemosynthesis-based carbon contribution in invertebrate nutrition was lower than that in HMMV.
\end{abstract}

Keywords: Cold-seep ; macrofaunal nutrition ; methane-derived carbon ; Norwegian margin ; stable isotope analysis 


\section{Introduction}

Cold-seep ecosystems are found along the wide bathymetric range of continental margins, where they are related to release of methane-enriched fluid or gas, often driven by tectonic processes. In these ecosystems, methane and sulphide are the two energy sources of the predominantly chemosynthesis-based production. Nevertheless, cold-seep ecosystems also receive variable input of organic matter from surface waters, according to depth and dynamic context. The importance of chemosynthetic nutritional pathways versus photosynthesis have been related to depth comparing seeps along the Eastern Pacific (Levin et al. 2000, Levin and Michener 2002) and along the Sakhalin margin (Sahling et al. 2003), revealing an increase of chemosynthetic contribution to invertebrate diets at the deepest sites where external inputs are lower than on continental shelf and slopes. From stable isotope analysis of animal tissues and source signatures, these authors estimated a methane derived carbon contribution of $0-20 \%$ for the shallowest California slope seeps (520 m depth) to 20 to $50 \%$ in the deepest along Alaska or Florida margins (>3000m). At $2000 \mathrm{~m}$ in the oligotrophic eastern Mediterranean, invertebrates associated with methane seeps on mud volcanoes are virtually exclusively fuelled by carbon of chemosynthetic origin with percentages of methane derived carbon varying among species between $0-33 \%$ (lower estimates) to $21-100 \%$ (upper estimates) (Carlier et al. 2010). Finally Thurber et al. (2010) reported a contribution of 21$73 \%$ of methane-derived carbon for the New Zealand seep fauna. Taking into account the whole community, chemosynthesis contribution is generally high in seep communities that are dominated by chemoautotrophic symbiont-bearing invertebrates (siboglinid polychaete tubeworms, mytilids, vesicomyid bivalves). Stable isotope signatures of non-symbiotic endemic species or opportunists also reveal high use of chemosynthesis-based carbon, relying directly or indirectly on free microbial communities (methane oxidizing archae or sulphur oxidizing filamenteous bacteria). These taxa include dorvilleid, polynoid, capitellid or ampharetid polychaetes, several grazers (gastropods, alvinocarid shrimps) or deposit feeders (sipunculids, echinoids, holothurids) (Levin et al. 2000, Van Dover et al. 2003, MacAvoy et al. 2005, Olu et al. 2009, Carlier et al. 2010). Higher level predators resident to seeps such as a few fish, large crustaceans, sea-stars or buccinid gastropods may have almost $100 \%$ reliance on seep production (MacAvoy et al. 2002). Large vagrant predators are abundant in bathyal depths and can also export chemosynthesis-based material from seeps (MacAvoy et al. 2002). A few fish also seem to export chemosynthetic material at deeper sites with up to $38 \%$ of seep material in their diet (Olu et al. 2009). Opportunistic taxa whose diet is mostly composed of decayed photosynthesis-based mater also consume small amounts of chemosynthetic production. The mean contribution of seep production is therefore balanced by species highly dependent from chemosynthesis, and opportunists and vagrant background fauna taking more or less benefit of local production.

The proportion of seep-dependent taxa may also vary according to habitats generally related to the intensity of the fluid flow. Biogenic structures created by large size symbiont-bearing species (Sibuet and Olu-Le Roy 2002), along with microbial mats, generate diverse habitats at seeps (Levin 2005), where small heterotrophic fauna live. Levin \& Michener (2002) and Levin \& Mendoza (2007) evidenced differences in $\delta^{13} \mathrm{C}$ signatures and then methane derived carbon contribution among habitats (microbial mats, vesicomyid fields, siboglinid fields) whatever the depth of the seeps.

The Håkon Mosby Mud Volcano is a 2-km diameter structure affected by high fluid, gas and mud expulsion and characterized by concentric distribution of habitats defined both visually by the occurrence of microbial mats, siboglinid fields, or bare sediment, and by geochemical gradients that also induce heterogeneity in microbial communities and processes (Jerosh et al. 2007, De Beer et al. 2006, Nieman et al. 2006). This site located at mid-slope (1200m) along the Norwegian margin, is therefore quite useful for testing the hypothesis that chemosynthetic material becomes less important along the gradient of geochemical and 
sulphur-oxidizing bacteria and occurrence of methanotrophic bacteria communities (Lösekann et al. 2007).

Other cold seeps have been recently discovered along the Norwegian margin, on the Storrega slide between 600 and $900 \mathrm{~m}$ depth (Foucher et al. subm). Patchy seepage areas are characterized by moderate fluid flow, but also revealed habitat zonation (microbial mats, siboglinid fields) around the fluid source, at decimetre to meter scales, colonised by fauna taxonomically related to HMMV one (Decker et al. subm.). Comparison of the spatially structured Mud Volcano with the communities associated with small-size seeps isolated within low active pockmarks, likely receiving higher detrital particulate fluxes, but characterized by similar habitat zonation than observed in the mud volcano is quite interesting in this context. We thus propose in this paper to compare isotopic signatures $\left(\delta^{13} \mathrm{C}\right.$ and $\left.\delta^{15} \mathrm{~N}\right)$ of invertebrates sampled by ROV in several habitats of the HMMV and of pockmarks of the Storrega slide (including Nyegga area) to assess the role of chemosynthetic vs. photosynthetic food sources in the nutrition of benthic communities $\left(\delta^{13} \mathrm{C}\right)$ and to unravel trophic relationships among their faunal components $\left(\delta^{13} \mathrm{C}\right.$ and $\left.\delta^{15} \mathrm{~N}\right)$. This multi-scale study aims to compare these patterns both among habitats within a seep site and between seeps and could help to assess habitat vs depth, seep size or activity influence on macro and megafaunal nutrition at seeps.

The following questions were addressed: (1) Do habitats influence macro-megafauna nutritional patterns, i.e. number and length of food chains and origin of carbon, along the geochemical gradient of the Håkon Mosby Mud Volcano?, (2) Do habitats also influence these characteristics at smaller and shallower seepage areas on pockmarks along the Norwegian margin?

\section{Study area}

\section{Håkon Mosby Mud Volcano}

The Håkon Mosby Mud Volcano (HMMV) $\left(72^{\circ} \mathrm{N}, 14^{\circ} 44^{\prime} \mathrm{E}\right)$ is located at $1250 \mathrm{~m}$ depth along the Norwegian margin (Vogt et al. 1997). The circular mud volcano comprises (1) a flat central and southern part interpreted as an area of recent mud flows; this flat area was called crater by Milkov et al. (2004), (2) a surrounding area characterized by a hummocky seafloor, interpreted to be composed of deformed old mud flows; (3) a pronounced moat at the periphery of the mud volcano (Foucher et al. 2010). The mud volcano is characterised by exceptionally high activity of fluid and gas ejections from the seabed with thermal and fluid flow gradients from the centre to the periphery (Milkov et al. 2004, Sauter et al. 2006, Feseker et al. 2008), and zonation of microbial activity and sediment geochemistry (De Beer et al. 2006, Niemann et al. 2006). Previous studies on HMMV revealed that chemosynthetic habitats are distributed according to these activity gradients with a central zone apparently devoid of fauna, an intermediate zone covered by microbial mats and a peripheral zone colonised by two species of symbiont-bearing siboglinid polychaetes, Sclerolinum contortum Smirnov, 2000 (Monilifera) and Oligobrachia haakonmosiensis Smirnov, 2000 (Frenulata) (Gebruk et al. 2003, Jerosch et al. 2007). The meiofaunal and macrofaunal communities associated with these habitats are clearly structured by habitat, with a few taxa in the centre of the volcano and a more diversified fauna in the peripheral siboglinid fields (Gebruk et al. 2003, Soltwedel et al. 2005, Van Gaever et al. 2006, Decker et al. subm). 


\subsection{Storegga Slide}

The Storegga Slide is a giant submarine land slide located in the southern part of the Norwegian margin $\left(64^{\circ} 45^{\prime} \mathrm{N}, 04^{\circ} 59^{\prime} \mathrm{E}\right)$, where some pockmarks have been discovered between 600 and $900 \mathrm{~m}$ depth (Hustoft et al. 2007, Paull et al. 2008, Foucher et al. 2009) (Fig 1). Few of these are presently active (Foucher et al. 2009). Deepage is dominated by advection of methane in solution in pore water, which could be derived from dissolution of hydrate in the chimney (Foucher et al. subm.). Chemosynthetic communities, similar in composition to those colonising HMMV, have developed in small areas, sparsely distributed around fluid sources (Decker et al. subm) but megafauna and particularly suspension feeders are abundant along the slope, both in and out of the pockmarks, likely in relation with high input of particulate organic matter (Foucher et al. subm.)..

\subsection{Nyegga area}

On the north-eastern flank of the Storegga Slide, in an area called Nyegga, one pockmark called G11 was discovered at 750 m depth, and surveyed by ROV (Hovland et al. 2005). Similar to the pockmarks found on the Storegga Slide, small, scattered seep areas have been observed in the Nyegga area with chemosynthetic communities distributed around fluid sources (Decker et al. subm). As on HMMV, microbial filaments comprise the communities nearest to the fluid source, surrounded by siboglinid fields of Sclerolinum cf. contortum and Oligobrachia cf. haakonmosiensis. A ring of small Rissoidae gastropods was observed at each seep between the microbial mats and the siboglinids.

Inside the G11 pockmark, small mounds called "pingoes", initially thought to be formed by gas hydrates (Hovland and Svensen 2006) were also observed. These mounds are colonised by siboglinid polychaetes Sclerolinum cf. contortum (Hovland and Svensen 2006, Vanreusel et al. 2009, Decker et al. subm). In contrast to HMMV, the Storegga Slide and the Nyegga area are characterised by an abundant background community and a high particulate fluid flow observed during the ROV dive.

\section{Materials and methods}

\subsection{Sampling strategy}

On HMMV, macrofauna $(\geq 250 \mu \mathrm{m})$ and magafauna (fauna visible on video-images) were sampled during the Vicking cruise (May-June 2006) aboard the R/V Pourquoi pas? with the ROV Victor 6000 (chief scientist, H. Nouzé). According to zonation, three different habitats were sampled (Figure 2) that correspond to sampling sites in Decker et al. (subm.): (1) white microbial mats (dominated by white filamentous bacteria); (2) sediment adjacent to microbial mats; (3) siboglinid polychaete fields dominated by S. contortum. On Storegga and Nyegga pockmarks, two habitats found near the fluid source were sampled: (1) microbial filaments surrounded by gastropods, (2) siboglinid fields composed of the two species $S$. cf. contortum and $O$. cf. haakonmosbiensis (Figure 3 ) as well as background megafauna in the vicinity of the seeps.

The macrofauna and megafauna were sampled using a suction sampler, manipulated by the ROV, and the ROV's grab arm. On HMMV, three replicates in each habitat were taken over a surface of $0.04 \mathrm{~m}^{2}$ delimited by four laser beams. On Storegga and Nyegga pockmarks, two replicates were taken in microbial filaments and three in siboglinid fields and in background sediment. On each habitat, replicates came from one contiguous habitat. To carry out 
isotope measurements, 1 to 20 individuals of the major and larger taxa $(\geq 1 \mathrm{~mm})$ were isolated and fixed in liquid nitrogen on board and then stored at $-80^{\circ} \mathrm{C}$ in the lab.

\subsection{Sample processing}

Samples for carbon and nitrogen isotope measurements were obtained from 17 macro- or megafauna taxa identified to the family level or higher on board. Molluscs were identified to the species level by Anders Warén and polychaetes to the family level by Marie Morineaux. From 1 to 20 individuals per taxon were used for analysis. Pooled individuals or alcoholpreserved individuals were used for small taxa, for which the amount of dry material of a single specimen was insufficient. In Table 2 are indicated the number of samples and the number of individuals pooled in each sample. Entire organisms were used for isotope analysis, with the exception of comatulids, ophiurids (for which analyses were performed on arms) and fishes (muscle tissue), which were dissected on board. For bivalves and tanaids preserved in alcohol, isotope signatures were corrected based on the comparison of alcoholand liquid nitrogen-preserved individuals. To assess the correction, individuals from five different taxa (siboglinid and capitellid polychaetes, pycnogonids, amphipods and gastropods) preserved in alcohol were analysed and compared to frozen individuals of the same taxa. The relationship between isotope signature of alcohol- and liquid nitrogenpreserved individuals is linear with $R^{2}>0.86$.

Organisms with carbonate skeleton were acidified in $4.75 \mathrm{M} \mathrm{HCl}$ to remove carbonate and then dried at $60^{\circ} \mathrm{C}$ for $72 \mathrm{~h}$. Other, non-acidified organisms were freeze-dried for $48 \mathrm{~h}$. After homogenization, about $1.0 \pm 0.5 \mathrm{mg}$ of material (precision: $0.001 \mathrm{mg}$ ) was weighed in tin capsules. For each sample, duplicates were prepared and sent to the Scottish Crop Research Institute in Scotland for analysis.

Samples were analysed using continuous-flow isotope-ratio mass-spectrometry (CF-IRMS) using a Sercon 20-20 stable isotope analyser with an ANCA-GSL solid/liquid preparation module (Sercon Ltd., Crewe, UK). Using the dual isotope mode, both $\delta^{15} \mathrm{~N}$ and $\delta^{13} \mathrm{C}$ were measured on the same sample (precision was $0.2 \%$ ). The methods are fully described in Scrimgeour and Robinson (2003). Carbon and nitrogen isotope ratios are expressed as $\delta$ [(delta)] values, \%o deviation from standard reference materials which are PDB (Pee Dee Belemnite ) for carbon, and atmospheric nitrogen for nitrogen (Peterson and Fry 1987):

$\delta X=\left[\left(R_{\text {samples }}-R_{\text {standard }}\right) / R_{\text {standard }}\right]$ * 1000

Where $\mathrm{X}={ }^{13} \mathrm{C}$ or ${ }^{15} \mathrm{~N}$ and $\mathrm{R}={ }^{13} \mathrm{C} /{ }^{12} \mathrm{C}$ or ${ }^{15} \mathrm{~N} /{ }^{14} \mathrm{~N}$.

\subsection{Data analysis}

Mean values and standard deviation of $\delta^{13} \mathrm{C}$ and $\delta^{15} \mathrm{~N}$ by taxa living in a habitat were calculated. Differences in $\delta^{13} \mathrm{C}$ or $\delta^{15} \mathrm{~N}$ signatures among taxa or habitats were tested using various non-parametric methods (Kruskal-Wallis test, non-parametric multiple comparisons). All analyses were performed using the free, open-source $R$ software (R Development Core Team 2008). The npmc library was used for non-parametric multiple comparisons (Helms and Munzel 2008).

Trophic relationships were inferred from both carbon and nitrogen signatures, based on enrichments of $\leq 1 \%$ in $\delta^{13} \mathrm{C}$ and $3.4 \%$ in $\delta^{15} \mathrm{~N}$, which are the generally accepted values that 
correspond to the change in stable isotopes between two successive trophic levels (Conway et al. 1994).

For each habitat and taxon, the percentage of methane-derived carbon in the diet was estimated using a two-source isotope mixing model (Fry and Sherr 1984). We used the equation employed by Levin and Michener. (2002):

$$
\mathrm{F}=\delta^{13} \mathrm{C}_{\mathrm{i}}-\delta^{13} \mathrm{C}_{\text {source } 2} / \delta^{13} \mathrm{C}_{\text {methane }}-\delta^{13} \mathrm{C}_{\text {source } 2}
$$

where $\mathrm{F}$ is the percentage of methane-derived carbon in the diet of the individual, and $\delta^{13} \mathrm{C}_{\mathrm{i}}$, the carbon isotopic signature of the taxon. As assumed by Levin \& Michener (2002), no trophic shift was included as negligible $\left(\leq 1 \%\right.$ per trophic level) for $\delta^{13} \mathrm{C}$. To have upper and lower estimates of methane-derived carbon in faunal tissues, two estimates were made with two different "source 2" end-members: the lower estimate $\left(F_{\mathrm{m} / \mathrm{soB}}\right)$ was obtained using $\delta^{13} \mathrm{C}$ signature of sulphide-oxidizing bacteria $\left(\delta^{13} \mathrm{C}_{\mathrm{SOB}}\right)$ and the upper estimate $\left(\mathrm{F}_{\mathrm{m} / \mathrm{POC}}\right)$ using $\delta^{13} \mathrm{C}$ signature of particulate organic carbon $\left(\delta^{13} \mathrm{C}_{\mathrm{POC}}\right)$. We used a $\delta^{13} \mathrm{C}_{\mathrm{POC}}$ value of $-22.11 \pm 0.6 \%$ from surface sediment sampled at a reference site out of the volcano (Van Gaever et al. 2006), a $\delta^{13} C_{\text {methane }}$ value of $-59.2 \%$ on HMMV (Lein et al. 1999), a $\delta^{13} C_{\text {methane value of }-57.9 \% \text { o }}$ on the Storegga Slide pockmark (Paull et al. 2008) and -69.3\%o for the G11 pockmark in the Nyegga area (Hovland et al. 2005). For $\delta^{13} \mathrm{C}_{\mathrm{SOB}}$, we used the signature of sulphur-oxidizing bacteria from mats on HMMV obtained in this study. The mean signature of $S$. cf. contortum sampled on Storegga slide, that probably contained the same sulphur-oxidizing symbionts as $S$. contortum on HMMV (Lösekann et al. 2008), was used for determining the proportion of chemosynthesis-derived carbon for Storegga Slide pockmark taxa as no estimation for $\delta^{13} \mathrm{C}$ sulphur-oxidizing bacteria from mats was available on these pockmarks. ,On HMMV, the $\delta^{13} \mathrm{C}$ of $S$. contortum and microbial mats were within 0.3 per mil only.

\section{Results}

\subsection{Stable isotope signatures}

The $\delta^{13} \mathrm{C}$ signatures of the 19 species of macro- and megafauna sampled respectively on the microbial mats (4 species), adjacent sediment (5 species), and siboglinid fields (10 species) on HMMV ranged from $-50.6 \%$ o to $-20 \%$ (Table 1, Figure 4). The most depleted taxa were those associated with microbial mats (Dorvilleidae and Capitellidae polychaetes, pygnogonids and Rissoidae gastropods) or sampled a few meters away in sediment (Amphipoda and Zoarcidae, which have the lightest $\delta^{13} \mathrm{C}$ ). Macrofaunal taxa associated with microbial mats and adjacent sediment had very depleted but homogeneous $\delta^{13} \mathrm{C}$ values, all between -45 and $-51 \%$, although the microbial mat signature had higher values $(-35.3 \pm$ $3.4 \%$ ) (Table 1). Capitellidae polychaetes and pycnogonids (Pantopoda) living on mats and in adjacent sediment showed similar carbon and nitrogen signatures in both habitats, while Rissoidae gastropods, Alvania sp., were less depleted in carbon in adjacent sediment than in microbial mats. Signature variability among individuals tended to be higher in adjacent sediment than on mats (e.g. Capitellidae) but the number of individuals analysed from sediment was generally higher and is likely a bias for this comparison.

The three sampled habitats were clearly separated according to macrofaunal $\delta^{13} \mathrm{C}$ signatures (Kruskal-Wallis: $p=0.001$ ). However, mats and adjacent sediment did not differ significantly (non-parametric multiple comparisons: $p=0.970$ ). Indeed, the mean signature of macrofauna associated with $S$. contortum fields had heavier $\delta^{13} \mathrm{C}$ values $(-27.0 \pm 5.7 \%$ ) than those of macrofauna on white microbial mats or the adjacent sediment $(-47.0 \pm 1.46 \%$ and $-47.04 \pm$ $4.0 \%$, respectively). 
In siboglinid fields, $\delta^{13} \mathrm{C}$ signatures had a larger range than in other habitats, from- $19.8 \%$ o to $35.0 \%$. Together with Sclerolinum contortum, Amphinomidae polychaetes and pygnogonids showed the most depleted signatures. Tanaids, Caprellidae amphipods, Thyasiridae bivalves and isopods had intermediate $\delta^{13} \mathrm{C}$ (between 25 and $30 \%$ ), while the ophiurids, the gastropod Cryptonatica affinis and Flabegilleridae polychaetes have higher $\delta^{13} \mathrm{C}$. Small crustaceans (amphipods, isopods and tanaids) showed variable $\delta^{13} \mathrm{C}$ signatures, suggesting heterogeneity of their food sources. The pygnogonids, the only taxa sampled in all three habitats, clearly differed in their carbon signature, being enriched at least of $10 \%$ in the siboglinid fields.

In the mats and adjacent sediments, $\delta^{15} \mathrm{~N}$ range was relatively narrow, from the mat itself with high sample variation $(-3.4 \% \pm \pm 3.1)$ to the Rissoidae gastropods $(7.2 \%$ ) while Zoarcidae fish had the heaviest value $(7.5 \pm 0.9 \%$ o) in the adjacent sediment community. The species sampled here had higher signatures in nitrogen than those from mats (e.g. Dorvilleidae polychaetes) that may derive their nutrition directly from microorganisms.

A larger $\delta^{15} \mathrm{~N}$ range was obtained from taxa sampled in siboglinid fields. Sclerolinum contortum had the lightest $\delta^{15} \mathrm{~N}$ value $(-1.7 \pm 0.9 \%$ ). Other polychaetes had different isotopic signatures according to their family, revealing different trophic levels. Nevertheless, $\delta^{15} \mathrm{~N}$ values were relatively uniform (average $+6.7 \%$ ) except for isopods that were higher in the trophic chain $(+9.4 \%)$. Gastropods Cryptonatica affinis had the highest $\delta^{15} \mathrm{~N}$ value $(+13.7 \%)$.

Unlike HMMV, the values of $\delta^{13} \mathrm{C}$ on the Storegga pockmark did not clearly differ among habitats (Kruskal-Wallis: $p=0.10$ ), but varied with taxa irrespective of the habitat from which they were sampled (Table 2, Figure 5). The different species of gastropods and of shrimps seemed to differ from each other by their signatures (except Alvania sp and Colus sabini), whatever their habitat, although these differences were not statistically significant (KruskalWallis:: $p=0.17)$. First, the two siboglinid species were distinct with lighter $\delta^{13} \mathrm{C}$ values for Oligobracchia. cf. haakonmosbiensis (-62.4 $\pm 4.8 \%$ ) than for $S$. cf. contortum $(-41.5 \pm 2.4 \%$ ) (Kruskal-Wallis, $\mathrm{p}<0.001$ ). Alvania sp. and Colus sabini gastropods, the polychaetes and one Caridae species (sp3) had depleted $\delta^{13} \mathrm{C}$ values ranging from -46 to $-42 \%$, whereas the Buccinum sp. gastropods, the echinoderms (holothurids, crinoids and ophiurids), and the other shrimps species (sp1 and sp2) had values ranging from $-30 \%$ o to $-18 \%$. Siboglinids and holothurids had the lowest nitrogen signatures, while the other taxa differed, with values ranging from 6 to $13 \%$. As observed for $\delta^{13} \mathrm{C}$ values, $\delta^{15} \mathrm{~N}$ values fluctuated among taxa but not among habitats. The highest $\delta^{15} \mathrm{~N}$ values were observed in the ophiurids Gorgonocephalus sp. (13.5\%o), Buccinum sp. (12.6\%o) and shrimps (average $11.5 \pm 0.4 \%$ ) .

As on Storegga pockmarks, on the G11 pockmark in Nyegga, habitats did not have distinct $\delta^{13} \mathrm{C}$ values (Kruskal-Wallis: $p=0.19$ ). However, taxa living far from seeps appeared to have heavier $\delta^{13} \mathrm{C}$ values than other taxa, although not statistically significant..Capitellid polychaetes that were abundant on microbial mats differed greatly from other taxa and had the lowest $\delta^{13} \mathrm{C}$ values, despite large variation $(-64.4 \pm 20.5 \%)$. For $\delta^{15} \mathrm{~N}$, siboglinids showed the lowest values, whereas the other taxa varied from $6 \%$ and $12 \%$. Whatever the habitat, Alvania sp. gastropods had a narrow range of signatures: $\delta^{13} \mathrm{C}$ ranged from $-37.2 \%$ o to $39.8 \%$ and $\delta^{15} \mathrm{~N}$ ranged from $6 \%$ oto $6.5 \%$. However, this taxon was probably composed of two species (A. Warén pers. com) that were not identified before analyses.

\subsection{Methane-derived carbon contribution}

According to the two-source isotope mixing model, macrofauna living on HMMV microbial mats or adjacent sediment depended mainly on chemosynthesis, whatever the carbon source used in the model (Table 1). The mean estimated contribution of methane-derived 
carbon ranged from $39 \%$ to $61 \%$ for mats (48 to $67 \%$, excluding the signature of the mat itself) and $49 \%$ to $67 \%$ for taxa in the adjacent sediment. Capitellids, zoarcids, amphipods and pycnogonids sampled on or close to the microbial mats were the taxa that depended the most on methane-derived carbon.

In siboglinid fields, the mean contribution of methane-derived carbon was 0 to $17 \%$ and the highest $36 \%$ for amphinomid polychaetes and pycnogonids. Most of the associated taxa (flabelligerid polychaetes, ophiurids, gastropods) seemed to mainly rely on photosynthesisbased carbon, with $\delta^{13} \mathrm{C}$ values of $>-30 \%$ and estimates of phytoplankton-derived carbon (1$\left.\mathrm{F}_{\mathrm{m} / \mathrm{POC}}\right)$ ranging from $89 \%$ to $100 \%$.

On the Storegga pockmark, the mean methane-derived carbon contribution was higher in siboglinid fields (32 to 62\%) than on microbial mats (5-29\%) (Table 2). Whatever the habitat, some macrofauna taxa (Buccinum sp., Caridae sp1) had slightly depleted $\delta^{13} \mathrm{C}$ signatures (> $-30 \%$ ), with percentages of methane-derived carbon as low as $0 \%$. Other taxa, including siboglinid, amphinomid and lumbrineid polychaetes, Alvania sp. and C. sabini gastropods mainly relied on chemosynthesis-derived carbon as shown by low $\delta^{13} \mathrm{C}$ signatures and high $F_{m / P O C}$ values. Except for $O$. cf. haakonmosbiensis, these taxa mainly depended on sulphideoxidizing derived carbon, as shown by the low methane contribution $\left(F_{m / s O B}<50 \%\right)$ but high chemosynthesis contribution $\left(\mathrm{F}_{\mathrm{m} / \mathrm{POC}}>50 \%\right)$ (Table 2$)$. Most taxa sampled in the vicinity of fluid seepage mainly relied on photosynthesis with less than $8 \%$ of methane-derived carbon, except Caridean shrimp sp3 and Alvania sp., whose signature did not vary between on- and off-seep habitats. The three species of shrimps (sp1, sp2 and sp3) greatly differed in their carbon signatures and their dependence on methane-derived carbon (except sp1 and sp2), showing no relationship with the habitat where they were sampled. The most depleted value of $\delta^{13} \mathrm{C}$ was observed off-seep (sp3) and the least depleted value also off-seep (sp1). The large echinoderms that were abundant around the seepage areas (holothurids, crinoids and ophiurids) showed only a limited consumption of methane-based carbon (0-8\%).

Similarly, on the G11 pockmark in the Nyegga area, some of the taxa living on siboglinid fields and off-seep depended on photosynthesis with a contribution ranging from 79 to $100 \%$ of photosynthesis-derived carbon $\left(1-\mathrm{F}_{\mathrm{m} / \mathrm{POC}}\right)$. However, Alvania sp. gastropods showed significant contributions of methane-based material in their diet whatever the habitat on and off seeps $(\mathrm{F}=4-43 \%)$. As on the Storegga pockmark, the shrimp signatures in the Nyegga differed among the two species. Other vagrant species such as amphipods did not rely, or relied very little, on methane, even those sampled on the microbial mats. Finally, the most depleted taxa were capitellid polychaetes with an estimation of $100 \%$ methane-derived carbon in the microbial filament habitat.

\section{Discussion}

\subsection{HMMV: a food web structured by habitat}

Stable isotope values of macrofauna and megafauna along the three study sites and estimation of the contribution of chemosynthesis to their nutrition showed that their diet is mainly based on chemosynthetic production. However, some taxa living in the active seep area or in the vicinity of fluid seepage partially or entirely rely on phytoplankton-derived carbon.

On HMMV, the first stable isotope analyses performed on a few macrofaunal taxa revealed high variability in carbon isotope signatures with a high contribution of methane-derived carbon (Gebruk et al. 2003). In a preliminary study, we observed that carbon isotope signature varies among habitats (Decker and Olu 2010). On microbial mats and in adjacent 
sediment, the contribution of methane-derived carbon was high (from $44 \pm 19 \%$ to $63 \pm 12 \%$ ). The nematod Geomonhystera disjuncta that dominate the meiofaunal compartment of microbial mats is assumed, based on its $\delta^{13} \mathrm{C}$ signature $(-41.6 \pm 0.4 \%$ o $)$ to depend on primary production by the sulphur-oxidizing Beggiatoa sp. mat-forming bacteria. $(-42.7 \pm 0.2)$ (Van Gaever et al. 2006). In our study, mats showed a heavier $\delta^{13} \mathrm{C}$ value $(-35.25 \pm 2.84 \%$ ), and this value was very different from that of most macrofauna living on mats or in adjacent sediment (average $-46.98 \pm 1.46 \%$ and $-47.04 \pm 4.01 \%$, respectively). The macrofauna living on microbial mats (capitellid and dorvilleid polychaetes, rissoid gastropods and pycnogonids) seemed to depend on methane-derive carbon $(41-71 \%)$, which may be produced by aerobic methanotrophic bacteria observed in the top centimetre of sediment of this habitat, or to a single species of anaerobic methanotrophic archaea (Lösekann et al. 2007). Fauna sampled on sediment adjacent to mats (amphipods, pygnogonids and zoarcid fishes) also rely on methanotrophically fixed carbon. Zoarcids were frequently seen making incursions on the mats during dives, and the microbial community may contribute to their diet. Two food chains may thus co-occur in this habitat, one based on sulphur oxidation and the other one based on aerobic or anaerobic methanotrophy. The negative correlation observed between meiofauna and macrofauna densities on HMMV (Van Gaever et al. 2009, Decker et al. subm), with dominance of nematodes on microbial mats, suggests that these two groups compete for food or space. The abundance of filamentous Beggiatoa mats compared to methanotrophic bacteria or archaea may favour nematodes over macrofaunal taxa in this habitat. The zoarcid fish could be a predator of pygnogonids and caprellids living in sediment adjacent to mats, and of capitellids living in the mat itself according to its nitrogen and carbon signatures. Zoarcids have been observed to make frequent visits to the mats but lie on the bottom in the bare adjacent sediment. They thus may help limit macrofaunal communities and to favour dominance of nematodes. Gut content analysis of the zoarcid fish are necessary to confirm this hypothesis.

In the $S$. contortum fields, the contribution of methane-derived carbon was lower than on microbial mats and varied among taxa (0 to $17 \pm 15 \%)$. Only a few taxa depended chiefly on chemosynthesis, namely Sclerolinum contortum and amphinomid polychaetes and pygnogonids, but methane-derived carbon was very low (0 to $35 \%$ ).

Length of food chains seems to vary among habitats and within the microbial mats and adjacent sediment habitat. Indeed, in these both habitats the food chain based on sulphuroxidation is about $9.8 \%$ o length whereas that based on methanotrophy is shorter $(5.8 \%$ length). On siboglinid fields, Sclerolinum contortum had the lowest $\delta^{15} \mathrm{~N}$ values and the various associated fauna corresponded to different levels of consumers $\left(\delta^{15} \mathrm{~N}\right.$ from 5.39 to $9.38 \%$ ). We can expect from two (microbial mats/sediment habitat) to four (siboglinid fields) trophic levels according to habitat. Occurrence of vagile megafauna in the first or second level consumers may help to export seep production out of the volcano. Nevertheless, the species sampled (ophiurids, Cryptonica. affinis) showed a low contribution of chemosynthesis-based material in their diet. Pycnogonida and smaller size crustaceans such as amphipods, isopods and tanaids seem to benefit more from local production but likely have a limited dispersion around the seep area and probably do not contribute much to exportation of local production. Zoarcidae also occur in siboglinid fields but have not been sampled there. Although not sampled, Rajidae are quite numerous and may play a role in exchanges with the background community.

On HMMV, the mean percentage of methane-derived carbon was clearly higher on microbial mats and in adjacent sediment (49\%-67\%) than in siboglinid fields $(0 \%-17 \%)$. This contrast between habitats has been observed on the Florida Escarpment with methane derived carbon contributing $50 \%$ on microbial mats and $23 \%$ in siboglinid fields (Levin and Mendoza 2007) (Fig. 6). Although the mean carbon signature of the fauna associated with HMMV microbial mats was not as low as in the Florida mat communities (Figure 6), the mean methane-derived carbon contribution was higher at HMMV due to a less depleted methane 
carbon signature (-59.2\%o versus -85\% HMMV versus the Florida escarpment, respectively). Other estimations of methane-derived carbon on mats are even lower, ranging from 20 to $44 \%$ on the Oregon Margin and from 0 to $5 \%$ on the California continental slope; however, depth influences the contribution of methane-derived carbon at these sites (Levin and Michener 2002). In contrast, siboglinid fields in the Gulf of Alaska have higher methanederived carbon estimates (32\% to 51\%) (Levin and Mendoza 2007) than those on HMMV (0 to $17 \%)$. Nevertheless, frenulate fields at the Uruti ridge off New Zealand have lower methane-derived carbon (0 to 1\%) than siboglinid fields on HMMV (Thurber et al. 2010) These differences may be related to depth and the influence of surface photosynthetic production that is higher in shallower sites; HMMV is located at $1200 \mathrm{~m}$ depth while the Alaska seeps are deeper than $3000 \mathrm{~m}$ and the Uruti ridge is at $716 \mathrm{~m}$. Another hypothesis is that the relatively mild environmental conditions in the siboglinid fields on HMMV (low sulphide concentrations and high penetration depth for oxygen (De Beer et al. 2006) allows penetration of vagrant species from the background environment.

On HMMV, the relative importance of methanotrophic vs. thiotrophic micro-organisms in the nutrition of invertebrates also varied, mainly among habitats, and most of the organic carbon was derived from sulphur-oxidizing bacteria $\left(\left(1-\mathrm{F}_{\mathrm{m} / \mathrm{soB}}\right)\right.$ average $\left.70 \%\right)$ except on microbial mats. In contrast, at the Blake Ridge seep site, where "methanotrophic" mussels form one of the habitats, most of the organic carbon derives from methane $(60 \%)$, which is similar to our mean estimation on HMMV microbial mats (49\%). However, as on HMMV mats, free-living thiotrophic bacteria also contribute to the nutrition of the invertebrate community associated with mussel beds (Van Dover et al. 2003).

\subsection{Storegga and Nyegga pockmarks: influence of external inputs}

The fluid seepage areas of the Storegga and Nyegga pockmarks are much more limited in space and did not show such a clear contrast in $\delta^{13} \mathrm{C}$ among habitats (Figure 3). Siboglinid species differed in their carbon signatures ( $S$. cf. contortum: $-41.46 \%$, $O$. cf. haakonmosbiensis: -62.37\%o), as previously shown by Van Gaever et al. (2006) and Lösekann et al. (2008) on HMMV. Like on HMMV, S. cf. contortum likely harbour sulfuroxidizing symbionts while the lighter $\delta^{13} \mathrm{C}$ value $(<50 \%$ ) of $O$. cf. haakonmobiensis indicated a methane-carbon origin. However, no methanotrophy genes (but those from sulphuroxidation) have been detected in Oligobracchia haakonmobiensis (Lösekann et al. 2008) and the chemoautotrophic process occurring in these species is still unresolved.

On seep areas of Storegga and Nyegga pockmarks, contrary to HMMV, no distinct food chains could be elucidated according to habitats (Figure 5). Indeed, signatures of vagrant fauna and their chemosynthetic-carbon contributions did not vary among habitats, but did among species (Table 2). Alvania sp. and C. sabini gastropods observed on or around microbial filaments probably graze on them. The $\delta^{13} \mathrm{C}$ signature of Alvania sp. and its low variability suggests that it may be endemic of seeps. Shrimps are scavengers (Segonzac et al. 1993, Iken et al. 2001), but the three shrimp species found on the pockmarks seem to differ in their use (or dependence) on chemosynthetic carbon production, as shown by their $\delta^{13} \mathrm{C}$ signatures. Indeed one species (sp1) seem to be totally independent of the seep production with signature close to $-20 \%$ whatever the habitat, contrasting with another (sp3) whose signature indicates significant chemosynthesis contribution in its diet. By contrast, the diet of the third species (sp2) found both in Storrega and Nyegga areas seems to vary according to the habitat where it was sampled (Table 2). On these two pockmarks, we sampled several background species (e.g. Buccinum sp., amphipods, one species of shrimp, holothurids, ophiurids and asteroids) that mostly relied on detritus-based production (1$\left.\mathrm{F}_{\mathrm{m} / \mathrm{POC}}>92 \%\right)$. While this is not as clear on Nyegga pockmarks, two food chains could cooccur on Storegga ones, one chain based on chemosynthetic production $\left(\delta^{13} \mathrm{C}\right.$ around $-40 \%$ ) and another one based on photosynthetic production $\left(\delta^{13} \mathrm{C}\right.$ around $-20 \%$ ). These chains 
have different length, $9.2 \%$ o to $12 \%$ respectively, suggesting 3 to 4 trophic levels. This pattern in which sites nearest the seeps lack a trophic level, was also observed on HMMV and could be explained by the absence of predators or scavengers adapted to high sulphide concentration, with the notable exception of the zoarcid fishes on HMMV (Decker et al. subm).

Comparing the volcano and pockmarks, the range of $\delta^{15} \mathrm{~N}$ and therefore the number of trophic levels, is higher on the pockmarks than on HMMV. The diversity of high-level consumers is much higher in the pockmarks than in the volcano with several species of shrimps, large gastropods and echinoderms whereas only ophiurids and the gastropod Crytonatica affinis were sampled in the HMMV Sclerolnum contortum fields. Exportation of seep production and methane derived carbon is likely much higher in the Storrega/Nyegga pockmarks than around the mud volcano. Although some have limited contribution of methane-derived carbon in their diet, several vagile megafauna taxa including shrimps, echinoderms and gastropods could contribute to the export of seep material to the background.

The Storegga Slide is probably an area that receives higher vertical or lateral fluxes of photosynthesis-produced material than HMMV. Visual observations during dives indicated high densities of particles in the water column and high densities of suspension feeders (sponges, Gorgonocephalus sp., crinoids, etc.) in the whole area (Foucher et al. subm.). HMMV is located deeper, is more isolated and is less likely to receive external inputs of organic matter. Moreover, the small size of scattered seepages (average $30 \mathrm{~cm}$ diameter) on the pockmarks, and their low fluid activity compared to the mud volcano probably encourage background fauna to make incursions to the seeps, even if some species do not utilise the chemosynthetic primary production. Similar observations have been made comparing the California continental slope and shelf and at Pacific seeps, where the nutrition of macrofauna of shallower sites is less influenced by seeps (Levin et al. 2000, Levin and Michener 2002). As shown in Figure 6, the mean signatures of macrofauna on microbial mats can vary greatly, from the Florida escarpment $(-56 \% ; 3300 \mathrm{~m})$ to the Eel River seeps ($22 \% ; 500 \mathrm{~m}$ ), and seem to be influenced by depth (Levin and Michener 2002). The mean macrofaunal signature on HMMV mats was located between signatures of the Florida escarpment mats and those of Oregon, while Storegga and Nyegga mat faunas had signatures with higher values, due to incursions of background species. Nevertheless, the pockmarks had more depleted signatures than Eel River mat fauna, because the pockmarks are inhabited by higher proportion of chemosynthesis-dependent species (endemic or opportunists) compared to vagrant background fauna that dominate at Eel River. For siboglinid-associated fauna, the sites with the most depleted values are the deepest coldseep sites studied: Gulf of Alaska seeps (-46\%, $4400 \mathrm{~m})$ and Unimak seeps (-24\%, $4400 \mathrm{~m})$, suggesting that depth is not the main controlling factor of macrofaunal nutrition in this habitat.

\section{Conclusion}

The isotopic signatures of the seep-associated fauna revealed food chains that were more or less distinct among habitats, according to the seep sites we explored. The signatures reflect differences in spatial patterns among seep sites, with very active mud volcano with a clear activity gradient from the centre to the periphery, and pockmarks characterised by mosaic of isolated fluid seepages with lower intensity and restricted in space, scattered in an area receiving higher external inputs. The mud volcano food chains contrasted with highly specialised fauna in habitats influenced by seep activity, while the nutritional patterns on 
pockmarks were less structured according to habitat but according to species. The less depleted macrofaunal $\delta^{13} \mathrm{C}$ signatures in Storegga pockmarks suggest that the seep size and their spatial organisation influence the distribution of seep endemic vs. background species in the different habitats and the relative importance of the seep production in food chains.

The occurrence of different food chains among but also within a same habitat as suggested for HMMV microbial mats strengthens the hypothesis of the importance of microbial communities in structuring the higher trophic levels, with potentially several parallel single, short food chains based on different microbial populations. Further investigations of the tight relationships between microbial diversity and functions and heterotrophic fauna are need to gain insight of the nutritional patterns in highly heterogeneous seep ecosystems.

\section{Acknowledgements}

We are grateful to the chief scientists and project leader of the VICKING cruise $(\mathrm{H}$. Nouzé, J.P. Foucher), and to the captain and the crew of the R/V Pourquoi pas? and the ROV Victor 6000 team. We thank our colleagues for their help on board: A. Andersen, J.C. Caprais, M.C. Fabri, P. Noël, L. Toffin, S. Van Gaever. The isotope measurements were processed by the Scottish Crop Research Institute. Polychaetes were identified by Marie Morineaux whose work was supported by the French ANR program DeepOases. We thank Anders Warén and Marie Morineaux for gastropod and polychaete identifications respectively, and Olivier Gauthier for the isotope plot R-function design. We are grateful to the two anynomous reviewers and to Pr. Craig Young, co-editor of Marine Ecology, for their useful comments to improve the manuscript. The English was professionally edited by Carolyn Engel-Gautier. The Vicking cruise was part of the FP6 European program HERMES, and this publication contributed to the FP7 European program Hermione.

\section{References}

Carlier, A., B. Ritt, C. Rodrigues, J. Sarrazin, K. Olu, J. Grall, and J. Clavier. 2010. Heterogeneous energetic pathways and carbon sources on deep eastern Mediterranean cold seep communities. Marine Biology 157:2545-2565.

Conway, N. M., M. C. Kennicutt, and C. L. Van Dover. 1994. Stable isotopes in the study of marine chemosynthetic-based ecosystems. Blackwell scientific publications, London.

De Beer, D., E. Sauter, H. Niemann, N. Kaul, J. P. Foucher, U. Witte, M. Schlüter, and A. Boetius. 2006. In situ fluxes and zonation of microbial activity in surface sediments of the Hâkon Mosby mud volcano. Limnology and Oceanography 51:1315-1331.

Decker, C., M. Morineaux, S. Van Gaever, J. C. Caprais, A. Lichtschlag, O. Gauthier, A. Andersen, and K. Olu. subm. Habitat heterogeneity influences cold-seep macrofaunal communities within and among seeps along the Norwegian margin. Part1: Macrofauna community structure. Marine Ecology.

Decker, C. and K. Olu. 2010. Does macrofauna nutrition vary among habitats at Håkon Mosby Mud Volcano ? Cahiers de Biologie Marine 51:361-367. 
Feseker, T., J. P. Foucher, and F. Harmegnies. 2008. Fluid flow or mud eruptions? Sediment temperature distributions on Håkon Mosby mud volcano, SW Barents Sea slope. Marine Geology 247:194-207.

Foucher, J. P., S. Dupré, C. Scalabrin, T. Feseker, F. Harmegnies, and H. Nouze. 2010. Changes in seabed morphology, mud temperature and free gas venting at the Håkon Mosby mud volcano, offshore northern Norway, over the time period 2003-2006. Geo-Marine Letters 30:157-167.

Foucher, J. P., C. Pierre, C. Decker, L. R. Rufine, S. Ker, G. Westbrook, K. Olu - Le Roy, J. P. Donval, and J. L. Charlou. subm. Seabed observations of methane seepage at Nyegga chimneys off mid-Norway. Results from the Vicking cruise (2006): . Marine Geology.

Foucher, J. P., G. Westbrook, A. Boetius, S. Ceramicola, S. Dupré, A. Mascle, J. Mienert, O. Pfannkuche, C. Pierre, and D. Praeg. 2009. Structure and drivers of cold-seep ecosystems. Oceanography 22:92-109.

Fry, B. and E. B. Sherr. 1984. delta 13C measurements as indicators of carbon flow in marine and freshwater ecosystems. Contributions in Marine Science 27:1346.

Gebruk, A., E. M. Krylova, A. Lein, G. M. Vinogradov, E. Anderson, N. V. Pimenov, G. A. Cherkashev, and K. Crane. 2003. Methane seep community of the Hakon Mosby mud volcano the Norvegian Sea: composition and trophic aspects. Sarsia 88:394-403.

Helms, J. and U. Munzel. 2008. Nonparametric Multiple Comparisons. CRAN.

Hovland, M., H. Svensen, C. F. Forsberg, H. Johansen, C. Fichler, J. H. Fossa, R. Jonsson, and $\mathrm{H}$. Rueslatten. 2005. Complex pockmarks with carbonate-ridges off mid-Norway: Products of sediment degassing. Marine Geology 218:191.

Hovland, M. and S. Svensen. 2006. Submarine pingoes: Indicators of shallow gas hydrates in a pockmark at Nyegga, Norwegian Sea. Marine Geology 228:1523.

Hustoft, S., J. Mienert, S. Buenz, and H. Nouze. 2007. High-resolution 3D-seismic data indicate focussed fluid migration pathways above polygonal fault systems of the mid-Norwegian margin. Marine Geology 245:89-106.

Iken, K., T. Brey, U. Wand, J. Voigt, and P. Junghans. 2001. Food web structure of the benthic community at Porcupine Abyssal Plain (NE Atlantic): a stable isotope analysis. Progress In Oceanography 50:383-405.

Jerosch, K., A. Lüdtke, M. Schlüter, and G. T. Ioannidis. 2007. Automatic contentbased analysis of georeferenced image data: Detection of Beggiatota mats in seafloor video mosaics from the Haakon Mosby Mud Volcano. Computer and Geosciences 33:202-218. 
Lein, A., P. Vogt, K. Crane, A. Egorov, and M. Ivanov. 1999. Chemical and isotopic evidence for the nature of the fluid in $\mathrm{CH}_{4}$-containing sediments of the Hakon Mosby Mud Volcano. Geo-Marines Letters 19:76-83.

Levin, L. A. 2005. Ecology of cold seep sediments: interactions of fauna with flow, chemistry and microbes. Oceanography and Marine Biology Annual Review 43:1-46.

Levin, L. A., D. W. James, C. M. Martin, A. Rathburn, L. Harris, and R. Michener. 2000. Do methane seeps support distinct infaunal assemblages? Observations on community structure and nutrition from the northern California slope and shelf. Marine Ecology Progress Series 208:21-39.

Levin, L. A. and G. F. Mendoza. 2007. Community structure and nutrition of deep methane-seep macrobenthos from the North Pacific (Aleutian) Margin and the Gulf of Mexico (Florida Escarpment). Marine Ecology-an Evolutionary Perspective 28:131-151.

Levin, L. A. and H. M. Michener. 2002. Isotopic evidence for chemosynthesis-based nutrition of macrobenthos: The ligntness of being at Pacific methane seeps. Limnology and Oceanography 47:1336-1345.

Lösekann, T., K. Knittel, T. Nadalig, B. Fuchs, H. Niemann, A. Boetius, and R. L. Amann. 2007. Diversity and abundance of Aerobic and Anaerobic Methane Oxidizers at the Haakon Mosby Mud Volcano, Barents Sea. Applied and Environmental Microbiology 73:3348-3362.

Lösekann, T., A. Robador, H. Niemann, K. Knittel, A. Boetius, and N. Dubilier. 2008. Endosymbioses between bacteria and deep-sea siboglinid tubeworms from an Arctic Cold Seep (Haakon Mosby Mud Volcano, Barents Sea). Environmental Microbiology 10:3237-3254.

MacAvoy, S. E., R. S. Carney, C. R. Fisher, and S. A. Macko. 2002. Use of chemosynthetic biomass by large, mobile, benthic predators in the Gulf of Mexico. Marine Ecology Progress Series 225:65-78.

MacAvoy, S. E., C. R. Fisher, R. S. Carney, and S. A. Macko. 2005. Nutritional associations among fauna at hydrocarbon seep communities in the Gulf of Mexico. Marine Ecology Progress Series 292:51-60.

Milkov, A., P. Vogt, K. Crane, A. Lein, R. Sassen, and G. Cherkashev. 2004. Geological, geochemical, and microbial processes at the hydrate-bearing Hakon Mosby Mud Volcano: a review. Chemical Geology 205:347-366.

Niemann, H., T. Losekann, D. de Beer, M. Elvert, T. Nadalig, K. Knittel, R. Amann, E. J. Sauter, M. Schluter, M. Klages, J. P. Foucher, and A. Boetius. 2006. Novel microbial communities of the Haakon Mosby mud volcano and their role as a methane sink. Nature 443:854-858.

Olu, K., J.-C. Caprais, J. Galéron, R. Causse, R. v. Cosel, H. Budzinsky, K. Le Ménach, C. Le Roux, A. Levaché, A. Khripounoff, and M. Sibuet. 2009. 
Influence of seep emission on the non-symbiont-bearing fauna and vagrant species at an active giant pockmark in the Gul fo fGuinea

(Congo-Angolamargin). Deep Sea Research II 56:2380-2393.

Paull, C. K., W. Ussler, W. Holbrook, T. M. Hill, R. Keaten, J. Mienert, H. Haflidason, J. E. Johnson, W. J. Winters, and T. D. Lorenson. 2008. Origin of pockmarks and chimney structures on the flanks of the Storegga Slide, offshore Norway. Geo-Marine Letters 28:43-51.

Peterson, B. J. and B. Fry. 1987. Stable isotopes in ecosystem studies. Annual Review of Ecology and Systematics 18:293-320.

Sahling, H., S. V. Galkin, A. Salyuk, J. Greinert, H. Foerstel, D. Piepenburg, and E. Suess. 2003. Depth-related structure and ecological significance of cold-seep communities--a case study from the Sea of Okhotsk. Deep Sea Research Part I: Oceanographic Research Papers 50:1391-1409.

Sauter, E. J., S. I. Muyakshin, J.-L. Charlou, M. Schlüter, A. Boetius, K. Jerosch, E. Damm, J.-P. Foucher, and M. Klages. 2006. Methane discharge from a deepsea submarine mud volcano into the upper water column by gas hydratecoated methane bubbles. Earth and Planetary Science Letters 243:354-365.

Scrimgeour, C. M. and D. Robinson. 2003. Stable isotope analysis and applications. Pages 381-431 in K. A. Smith and M. S. Cresser, editors. Soil and Environmental Analysis: Modern Instrumental Techniques. Marcel Dekker Inc., New York.

Segonzac, M., M. Saint-Laurent (de), and B. Casacova. 1993. L'énigme du comportement trophique des crevettes Alvinocarididae des sites hydrothermaux de la dorsame médio-atlantique. . Cahiers de Biologie Marine 34.

Sibuet, M. and K. Olu-Le Roy. 2002. Cold Seep Communities on Continental Margins: Structure and Quantitative Distribution Relative to Geological and Fluid Venting Patterns. Pages 235-251 in D. B. G. Wefer, D. Hebbeln, B.B. Jorgensen, T. Van Weering, editor. Ocean Margin Systems. Springer Verlag, Berlin.

Soltwedel, T., D. Portnova, I. Kolar, V. Mokievsky, and I. Schewe. 2005. The smallsized benthic biota of the Hakon Mosby Mud Volcano (SW Barents Sea slope). Journal of Marine Systems 55:271.

Thurber, A. R., K. Kroger, C. Neira, H. Wiklund, and L. A. Levin. 2010. Stable isotope signatures and methane use by New Zealand cold seep benthos. Marine Geology 272:260-269.

Van Dover, C., P. Aharon, J. M. Bernhard, E. Caylor, M. Doerries, W. Flickinger, W. Gilhooly, S. K. Goffredi, K. Knick, S. A. Macko, S. Rapoport, E. C. Raulfs, C. Ruppel, J. Salerno, R. D. Seitz, B. K. Sen Gupta, T. Shank, M. Turneipseed, and R. C. Vrijenhoek. 2003. Blake Ridge methane seep: characterization of a soft-sediment, chemosynthetically based ecosystem. Deep-Sea Research I 50:281-300. 
Van Gaever, S., L. Moodley, D. de Beer, and A. Vanreusel. 2006. Meiobenthos at the Arctic Håkon Mosby Mud Volcano, with a parental-caring nematode thriving in sulphide-rich sediments. Marine Ecology Progress Series 321:143-155.

Van Gaever, S., K. Olu, S. Derycke, and A. Vanreusel. 2009. Metazoan meiofaunal communities at cold seeps along the norwegian margin: Influence of habitat heterogeneity and evidence for connection with shallow-water habitats. Deep Sea Research Part I: Oceanographic Research Papers 56:772-785.

Vanreusel, A., A. C. Andersen, A. Boetius, D. Connelly, M. R. Cunha, C. Decker, K. Heeschen, A. Hilario, K. A. Kormas, L. Maignien, K. Olu, M. Pachiadaki, B. Ritt, C. Rodrigues, J. Sarrazin, P. A. Tyler, S. Van Gaever, and H. Vanneste. 2009. Biodiversity of Cold Seep Ecosystems Along the European Margins. Oceanography 22:118-135.

Vogt, P. R., G. Cherkashev, G. Ginsburg, G. Ivanov, A. Milkov, K. Crane, A. Lein, E. Sundvor, N. Pimenov, and A. Egorov. 1997. Haakon Mosby mud volcano provides unusual example of venting. Eos 78:549-557. 


\section{Tables}

Table 1: Isotope signatures: $\delta^{13} \mathrm{C}$ and $\delta^{15} \mathrm{~N}(\mathrm{SD})$ and methane: $\mathrm{F}_{\mathrm{m} / \mathrm{sOB}}-\mathrm{F}_{\mathrm{m} / \mathrm{POC}}$ contribution in the diet of major taxa sampled in different habitats on HMMV (N: number of individuals or pooled samples, $(n)$ is the total number of individuals sampled before pooling). See text for $F_{m / s o B}$ and $\mathrm{F}_{\mathrm{m} / \mathrm{POC}}$ estimations.

\begin{tabular}{|c|c|c|c|c|c|c|c|c|c|c|c|c|}
\hline \multirow[b]{2}{*}{ Taxon } & \multicolumn{4}{|c|}{ White microbial mats } & \multicolumn{4}{|c|}{ Adjacent sediment } & \multicolumn{4}{|c|}{ S. contortum field } \\
\hline & $N(n)$ & $\delta{ }^{13} \mathrm{C}(\mathrm{SD})$ & ${ }^{\delta^{15}} \mathrm{~N}(\mathrm{SD})$ & $\begin{array}{l}\mathrm{F}_{\mathrm{m} / \mathrm{SOB}^{-}} \\
\mathrm{F}_{\mathrm{m} / \mathrm{POC}}\end{array}$ & $N(n)$ & $\delta^{13} \mathrm{C}(\mathrm{SD})$ & ${ }^{\delta_{15}} \mathrm{~N}(\mathrm{SD})$ & $\begin{array}{l}\mathrm{F}_{\mathrm{m} / \mathrm{SOB}^{-}} \\
\mathrm{F}_{\mathrm{m} / \mathrm{POC}}\end{array}$ & $N(n)$ & $\delta^{13} \mathrm{C}(\mathrm{SD})$ & ${ }^{15} \mathrm{~N}(\mathrm{SD})$ & $\begin{array}{l}\mathrm{F}_{\mathrm{m} / \mathrm{SOB}^{-}} \\
\mathrm{F}_{\mathrm{m} / \mathrm{POC}}\end{array}$ \\
\hline $\begin{array}{l}\text { HMMV } \\
\text { White microbial } \\
\text { mats } \\
\text { Polychaeta }\end{array}$ & 5 & $-35.3(2.8)$ & $-3.4(3.1)$ & $0.00-0.35$ & & & & & & & & \\
\hline S. contortum & & & & & & & & & $4(20)$ & $-35.0(0.2)$ & $-1.7(0.9)$ & $0.00-0.35$ \\
\hline $\begin{array}{l}\text { Amphinomidae } \\
\text { Capitellidae }\end{array}$ & $2(15)$ & $-47.8(0.3)$ & $2.9(0.7)$ & $0.52-0.69$ & $8(15)$ & $-47.6(7.1)$ & $3.8(0.8)$ & $0.51-0.69$ & $3(9)$ & $-34.9(2.8)$ & $7.1(2.3)$ & $0.00-0.35$ \\
\hline $\begin{array}{l}\text { Dorvilleidae } \\
\text { Flabelligeridae }\end{array}$ & $1(10)$ & -48.4 & 1.4 & $0.54-0.71$ & & & & & 9 & $-19.8(0.4)$ & $8.8(0.4)$ & 0.00 \\
\hline $\begin{array}{l}\text { Bivalvia } \\
\text { Thyasiridae } \\
\text { Gastropoda }\end{array}$ & & & & & & & & & $5(20)$ & $-27.2(0.9)$ & $5.4(1.8)$ & $0.00-0.17$ \\
\hline $\begin{array}{l}\text { Cryptonatica affinis } \\
\text { Alvania sp. } \\
\text { Amphipoda }\end{array}$ & $1(20)$ & -46.6 & 7.2 & $0.47-0.66$ & $\begin{array}{l}1(10) \\
3(9)\end{array}$ & $\begin{array}{l}-40.2 \\
-50.6(0.2)\end{array}$ & $\begin{array}{l}6.0 \\
5.2(0.5)\end{array}$ & $\begin{array}{l}0.21-0.49 \\
0.64-0.77\end{array}$ & $1(2)$ & -20.0 & 13.7 & 0.00 \\
\hline $\begin{array}{l}\text { Caprellidae } \\
\text { Isopoda }\end{array}$ & & & & & & & & & $\begin{array}{l}3 \\
4(8)\end{array}$ & $\begin{array}{l}-28.6(2.7) \\
-26.3(0.8)\end{array}$ & $\begin{array}{l}6.8(0.5) \\
9.4(0.7)\end{array}$ & $\begin{array}{l}0.00-0.19 \\
0.00-0.13\end{array}$ \\
\hline Tanaidacea & & & & & & & & & $1(3)$ & -29.3 & 7.3 & $0.00-0.21$ \\
\hline Pantopoda & 1 & -45.1 & 4.6 & $0.41-0.62$ & 8 & $-47.8(4.1)$ & $4.6(1.0)$ & $0.52-0.69$ & 6 & $-34.8(1.9)$ & $6.1(2.2)$ & $0.00-0.35$ \\
\hline $\begin{array}{l}\text { Ophiuroidea } \\
\text { Zoarcidae }\end{array}$ & & & & & 4 & $-49.0(4.2)$ & $7.5(0.9)$ & $0.57-0.72$ & 1 & -22.2 & 9.3 & $0.00-0.02$ \\
\hline $\begin{array}{l}\text { Mean signature and } \\
\text { methane-derived } \\
\text { carbon (SD) }\end{array}$ & & & & $\begin{array}{l}0.39(0.22) \\
- \\
0.61(0.15)\end{array}$ & & & & $\begin{array}{l}0.49(0.17) \\
- \\
0.67(0.11)\end{array}$ & & & & $\begin{array}{l}0.00- \\
0.17(0.15 \\
)\end{array}$ \\
\hline
\end{tabular}


Table 2: Isotope signatures: $\delta^{13} \mathrm{C}$ and $\delta^{15} \mathrm{~N}(\mathrm{SD})$ and methane: $\mathrm{F}_{\mathrm{m} / \mathrm{SOB}}-\mathrm{F}_{\mathrm{m} / \mathrm{POC}}$ contribution in the diet of major taxa sampled in different habitats on Storegga and Nyegga pockmarks ( $N$ : number of samples, $(n)$ number of individuals pooled by sample). See text for $F_{m / s o B}$, $F_{m / P o c}$ estimations. Values for $S$. cf contortum sampled on the «pingoe » were underlined.

\begin{tabular}{|c|c|c|c|c|c|c|c|c|c|c|c|c|}
\hline & \multicolumn{4}{|c|}{ White microbial filaments and gastropods } & \multicolumn{4}{|c|}{ Siboglinidae field } & \multicolumn{4}{|c|}{ Individuals in the vicinity of fluid seepage } \\
\hline & $N(n)$ & $\delta{ }^{13} \mathrm{C}(\mathrm{SD})$ & ${ }^{15} \mathrm{~N}(\mathrm{SD})$ & $\begin{array}{l}\mathrm{F}_{\mathrm{m} / \mathrm{SOB}^{-}} \\
\mathrm{F}_{\mathrm{m} / \mathrm{POC}}\end{array}$ & $N(n)$ & $\delta{ }^{13} \mathrm{C}(\mathrm{SD})$ & $\begin{array}{l}\delta \\
{ }^{15} \mathrm{~N}(\mathrm{SD})\end{array}$ & $\begin{array}{l}\mathrm{F}_{\mathrm{m} / \mathrm{SOB}} \\
\mathrm{F}_{\mathrm{m} / \mathrm{POC}}\end{array}$ & $N(n)$ & $\delta^{13} \mathrm{C}(\mathrm{SD})$ & ${ }^{\delta} \mathrm{N}(\mathrm{SD})$ & $\begin{array}{l}\mathrm{F}_{\mathrm{m} / \mathrm{SOB}} \\
\mathrm{F}_{\mathrm{m} / \mathrm{POC}}\end{array}$ \\
\hline \multicolumn{13}{|l|}{ Storegga pockmark } \\
\hline haakonmosbiensis & & & & & $12(10)$ & $-62.4(4.8)$ & $3.7(0.6)$ & 1 & & & & \\
\hline S.cf.contortum & & & & & $7(20)$ & $-41.5(5.1)$ & $2.4(0.4)$ & $0-0.54$ & & & & \\
\hline Amphinomidae & & & & & 1 & -45.8 & 10.8 & $0.27-0.66$ & & & & \\
\hline Alvania sp. & $10(10)$ & $-42.1(3.6)$ & $\begin{array}{l}7.4(0.8) \\
12.4\end{array}$ & $0.04-0.56$ & & & & & $3(10)$ & $-42.8(2.8)$ & $\begin{array}{l}7.1(0.3) \\
12.6\end{array}$ & $0.08-0.58$ \\
\hline Buccinum sp. & 2 & $-19.5(2.1)$ & $(0.4)$ & 0.00 & & & & & 4 & $-18.8(0.9)$ & $(0.9)$ & 0.00 \\
\hline Colus sabini & 3 & $-43.9(1.8)$ & $7.7(0.6)$ & $0.15-0.61$ & & & & & & & & \\
\hline Copepoda & & & & & & & & & 1 & -22.9 & 6.2 & $0-0.04$ \\
\hline Caridea & & & & & & & & & & & & \\
\hline Caridea sp1 & 4 & $-20.5(2.0)$ & $\begin{array}{l}11.2 \\
(3.4)\end{array}$ & 0.00 & & & & & 4 & $-19.6(2.0)$ & $\begin{array}{l}11.0 \\
(2.3) \\
11.6\end{array}$ & 0.00 \\
\hline Crinoidea & & & & & & & & & 18 & $-22.2(1.5)$ & $8.4(1.6)$ & $0-0.02$ \\
\hline Ophiuroidea & & & & & & & & & & & & \\
\hline Gorgonocephalus & & & & & & & & & & & 13.5 & \\
\hline$s p$. & & & & & & & & & 3 & $-18.5(0.6)$ & $(0.6)$ & 0.00 \\
\hline $\begin{array}{l}\text { Mean methane- } \\
\text { derived carbon (SD) }\end{array}$ & & & & $\begin{array}{l}0.05(0.07) \\
- \\
0.29(0.34)\end{array}$ & & & & $\begin{array}{l}0.32 \\
(0.47)- \\
0.62 \\
(0.32)\end{array}$ & & & & $\begin{array}{l}0.02(0.04) \\
- \\
0.15(0.25)\end{array}$ \\
\hline
\end{tabular}




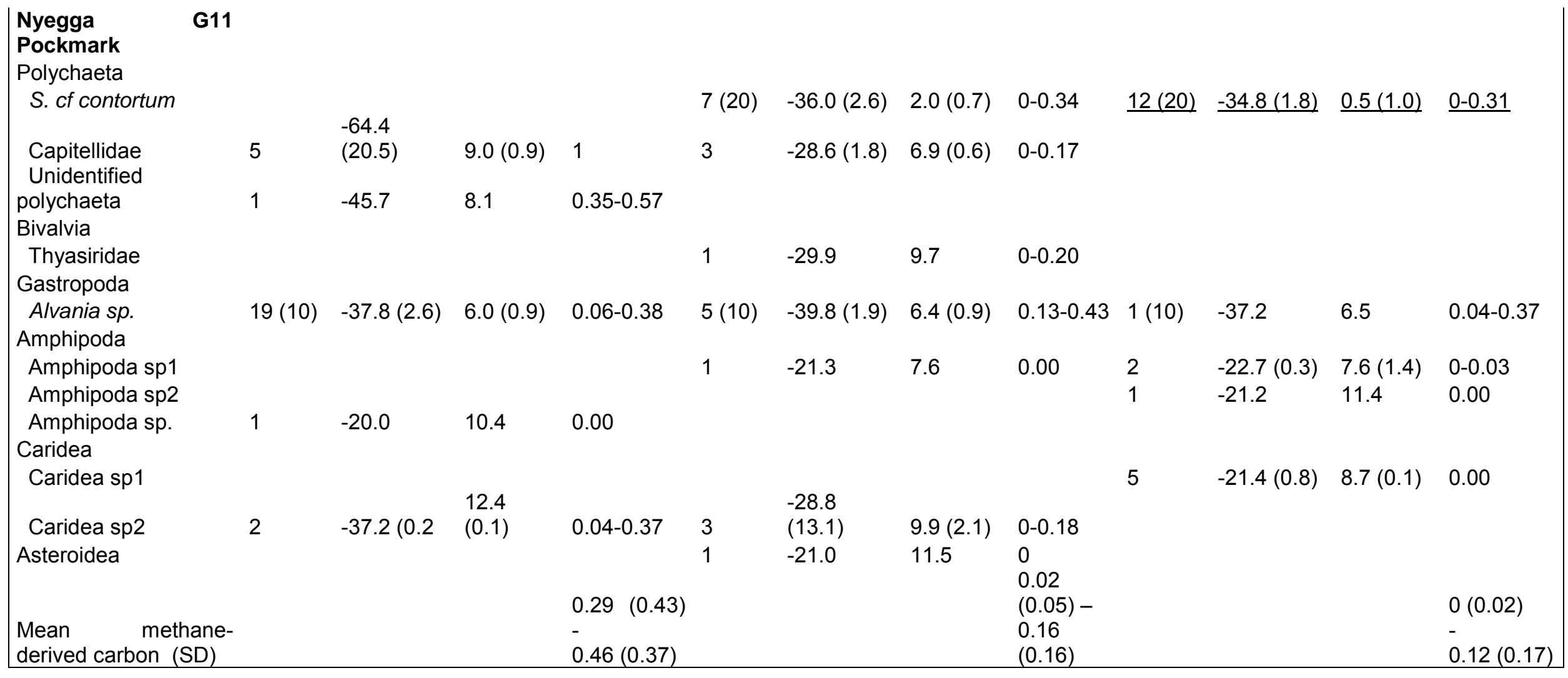




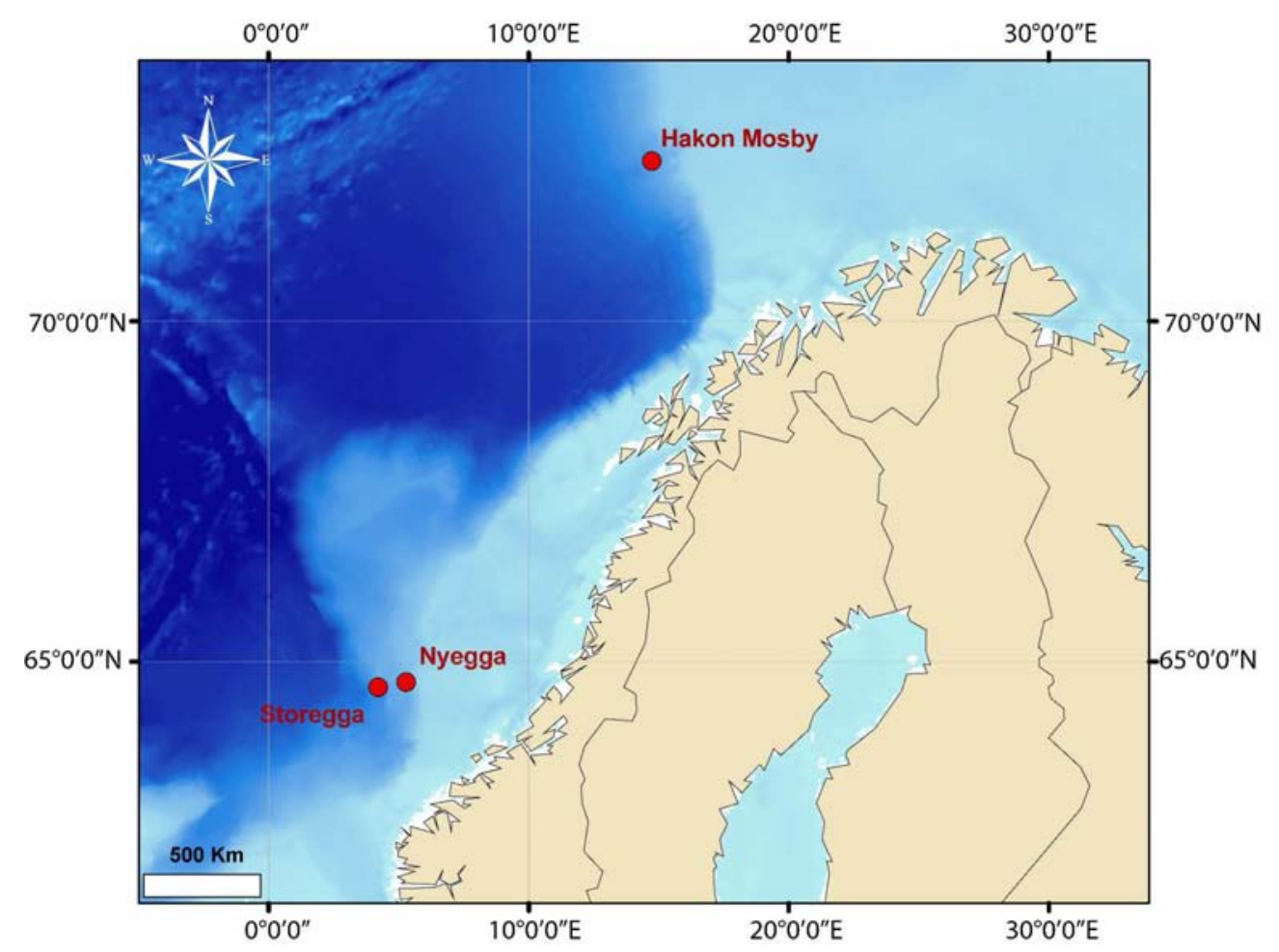

Figure 1: Location of the three sites sampled: Håkon Mosby mud volcano and the Storegga Storegga and Nyegga (G11) pockmarks. $291 \times 225 \mathrm{~mm}(300 \times 300 \mathrm{DPI})$ 


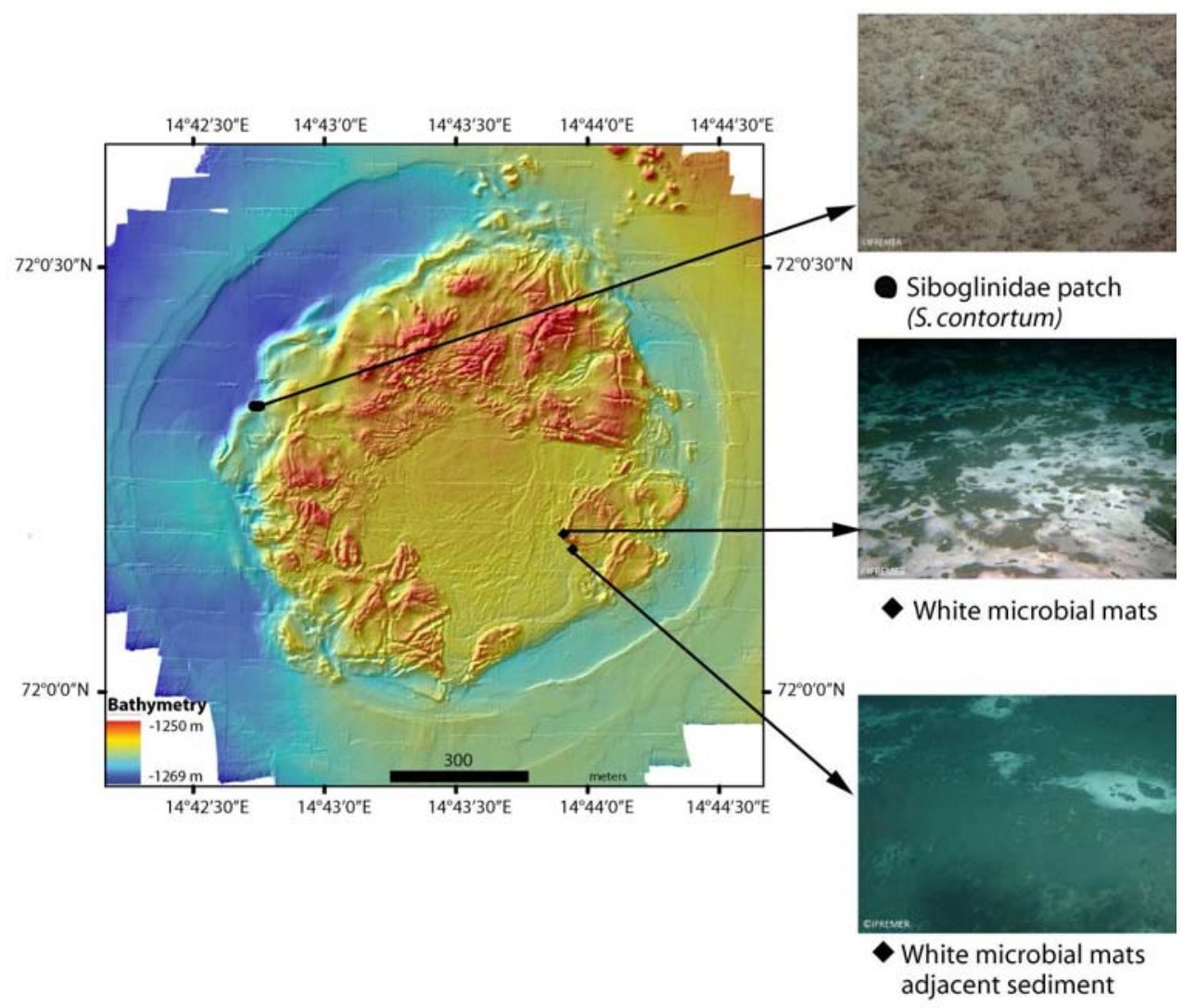

Figure 2: Location of the three habitats sampled on the Håkon Mosby mud volcano. $135 \times 124 \mathrm{~mm}(300 \times 300$ DPI $)$ 


\section{Page 35 of 38} 1 2 3

4

5

6

7 10
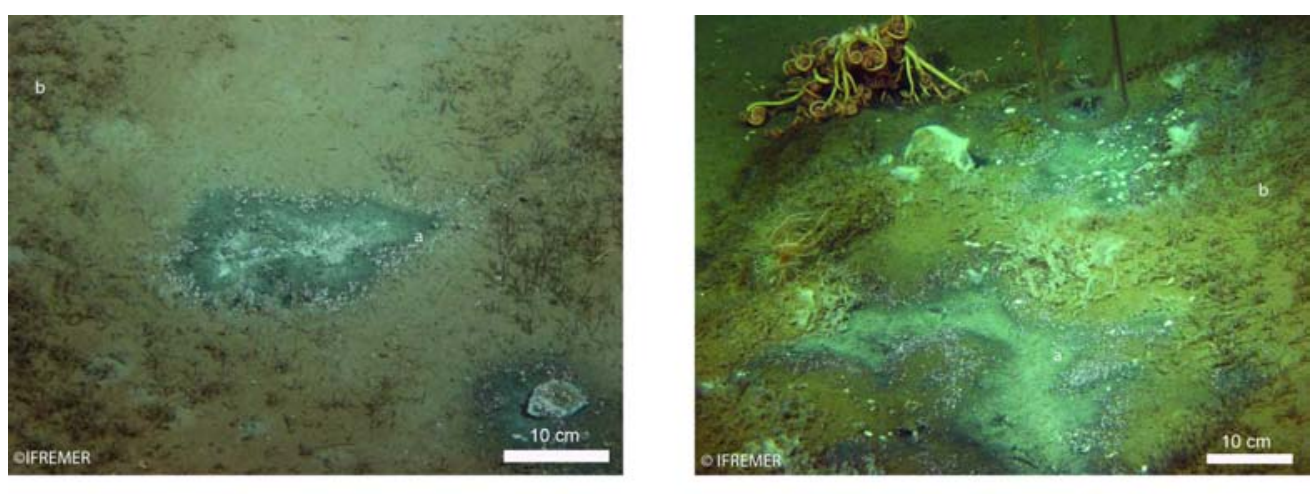

1

Figure 3: The two types of habitats sampled on Storegga and Nyegga pockmarks: a) white microbial filaments and gastropods; b) Siboglinid field. $191 \times 78 \mathrm{~mm}(300 \times 300 \mathrm{DPI})$ 


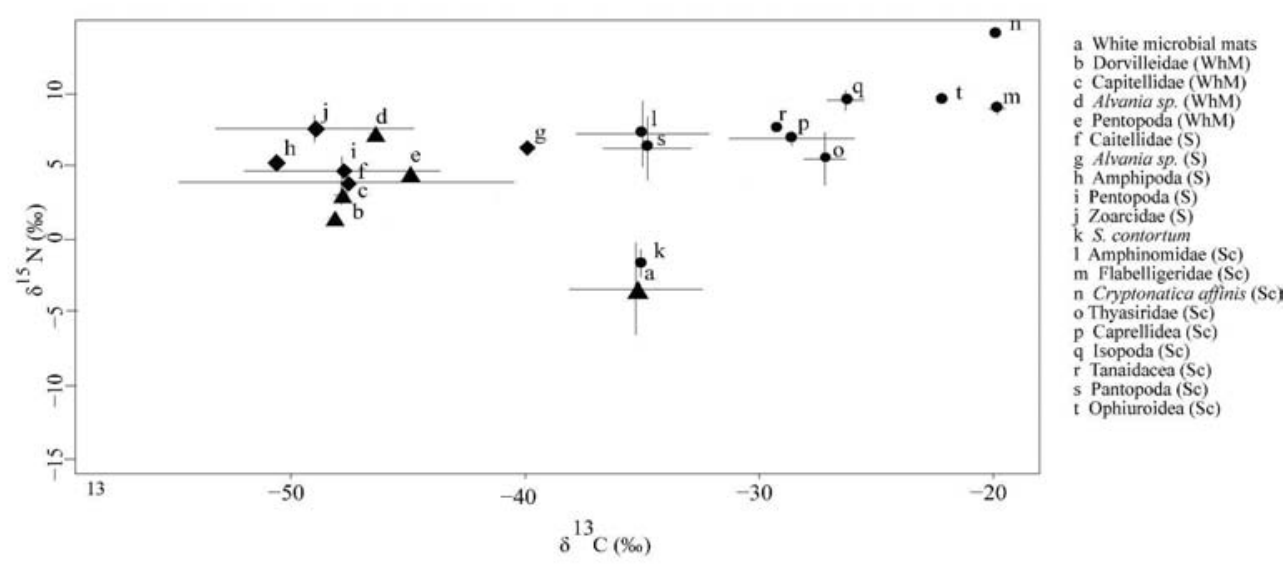

Figure 4: Isotope signatures of different taxa on Håkon Mosby mud volcano ( $\mathrm{p}$ : macrofauna on white microbial mats (WhM), $\dot{c}$ : macrofauna on white mats in adjacent sediment (S), Â』 : macrofauna in siboglinid fields (Sc)). Bares indicated standard deviation. $432 \times 198 \mathrm{~mm}(300 \times 300 \mathrm{DPI})$ 


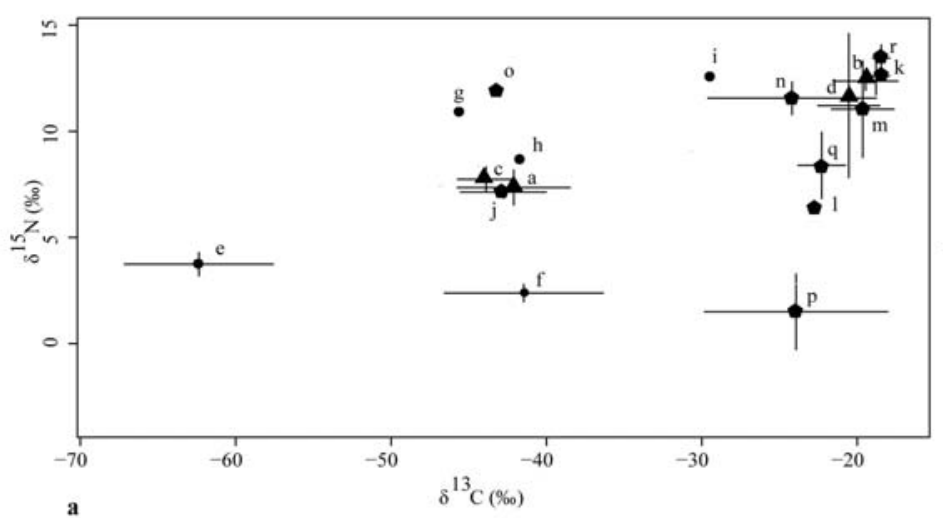

a Alvania sp. (WhM/G) b Buccimum sp. (WhM/G) c Colus sabini (WhM/G) d Caridea spl (WhM/G) e $O$. cf haakonmosbiensis S. cf contortum h Amphinomidae (Sc) i Caridea sp2 ( $S c)$ j. Alvania sp. (Vic) k Buccimum sp. (Vic) 1 Copepoda (Vic) $\mathrm{m}$ Caridea spl (Vic) n Caridea sp2 (Vic) - Caridea sp3 (Vic)

p Holothuroidea (Vic)

q Crinoidea (Vic)

r Gorgonocephalus sp (Vic)

a

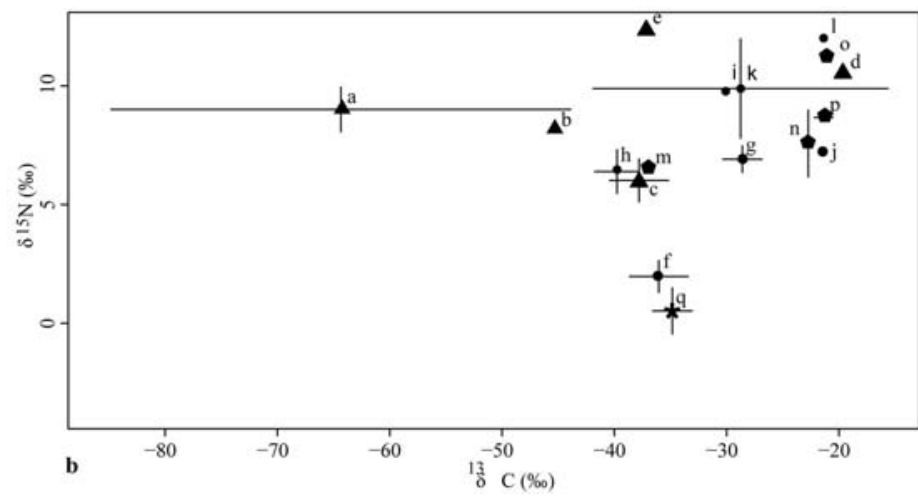

Capitellidae (WhM/G)

Polychaeta unidentified (WhM/G)

c Alvania sp. (WhM/G)

d Amphipoda (WhM/G)

e Caridea sp2 $(\mathrm{WhM} / \mathrm{G})$

f $S$. cf contortum

g Capitellidae (Sc)

Bivavia $(\mathrm{Sc})$

j Amphipoda spl (Sc)

$\mathrm{k}$ Caridea sp2 ( Sc)

1 Asteroidea $(\mathrm{Sc})$

$\mathrm{m}$ Alvania sp. (Vic)

o Amphipoda sp2 (Vic)

p Caridea sp1 (Vic)

Figure 5: Isotope signatures of different taxa on the pockmarks: $a$ : Storegga pockmark and b: Nyegga pockmark ( $\mathrm{p}$ : macrofauna on white microbial mats and gastropods (WhM/G), Âl : macrofauna in siboglinid fields (Sc), À: macrofauna in the vicinity of fluid seepage (Vic)). Bares indicated standard deviation.

$$
233 \times 194 \mathrm{~mm}(300 \times 300 \text { DPI })
$$


Figure 6: Isotope signatures and macrofauna associated with habitats in different seep areas around the world: $\square$ : Håkon Mosby mud volcano $(-1250 \mathrm{~m})$ (this study); À: Storegga and Nyegga pockmarks $(-750 \mathrm{~m})$ (this study); Âl : Florida escarpment $(-3300 \mathrm{~m})$; $\square$ : Oregon margin $(600-$ $800 \mathrm{~m})$ and Eel river $(-500 \mathrm{~m}) ; \square$ : Gulf of Alaska $(-4400 \mathrm{~m})$, Kodiak $(-3300 \mathrm{~m})$ and Unimak $(-4400 \mathrm{~m})$ (Levin and Michener 2002, Levin and Mendoza 2007). Bares indicated standard deviation. $492 \times 243 \mathrm{~mm}(300 \times 300 \mathrm{DPI})$ 